\title{
Interprofessional collaboration strategies: A hematology unit case study
}

\author{
Lu Xia ${ }^{1}$, Huixin $\mathrm{Wu}^{2}$, Yun Cheng ${ }^{* 1}$ \\ ${ }^{1}$ Shanghai Huadong Hospital, Shanghai, China \\ ${ }^{2}$ Chatham University, Pittsburgh, United States
}

Received: April 1, 2016

DOI: $10.5430 /$ jnep.v7n4p51
Accepted: November 22, $2016 \quad$ Online Published: November 23, 2016

URL: http://dx.doi.org/10.5430/jnep.v7n4p51

\begin{abstract}
Interprofessional collaboration is essential to improve patient outcomes in hematology units. We report on the case of a patient with severe aplastic anemia who died after a fall in a hematology unit and explore the events of the case within the context of interprofessional collaboration. Several strategies were taken into consideration suggested by the Interprofessional Education Collaborative Expert Panel. A regular team meeting is helpful for gaining information about patients. Multidisciplinary education can enhance cooperation among medical team members and the use of an interprofessional curriculum at university level is recommended. Team building, interprofessional education, and clinical practice may facilitate health care providers to reach a collaborative level of clinical practice in a more considerate manner, to meet the demands of high quality health care.
\end{abstract}

Key Words: Interprofessional collaboration, Interdisciplinary education, Hematology unit

\section{INTRODUCTION}

Effective teamwork and communication among healthcare professionals is essential to patient safety. In recent years, multidisciplinary disease management programs have been developed in Europe and the United States to reduce the frequency, severity and cost of adverse clinical events. ${ }^{[1]}$ To keep up with developments in multidisciplinary treatment, interprofessional collaboration strategies should be addressed.

\section{Background}

Expansion of the scope of practice for health care professionals such as nurses, physicians, pharmacists, and dieticians, may include, but is not limited to, the assessment, prescription and monitoring of therapy as part of collaborative efforts. This provides an opportunity to successfully achieve patient safety goals. ${ }^{[2]}$ Interdisciplinary communication in clinical settings assists in ensuring the entire multidisciplinary treatment procedure is carried out safely and effectively. ${ }^{[3]}$

\section{CASE REPORT}

At the end of the hallway in a hematology unit, approximately 10 people were crying, shouting, and lying or sitting on the ground. One of the men held a giant photograph in his arms. It was a picture of a smiling woman in her 40s. This woman had had severe aplastic anemia for many years; she was resistant to most treatment and her health state had deteriorated. Her family had decided to sell their property and borrow money for hematopoietic stem cell transplantationShe lived in a private lamina flow room to prevent her from acquiring infections.

The RNs (Registed Nurses, RNs) asked the patient use a China.

*Correspondence: Yun Cheng; Email: yun91@ hotmail.com; Address: 221 West Yan'an Road, Nursing Department, Huadong Hospital, Shanghai, 
bedpan to empty her bowel/bladder, as her low levels of hemoglobin and platelets meant that any small movement may cause a spontaneous hemorrhage. However, the patient did not follow the nurses' directions and she unfortunately fell on the ground. Her physician informed the patient's family, who did not visit her in the room for infection control reasons, that she was improving. However, the nurses noticed that the patient was not able to perform activities of daily living as she used to. The patient's family members continued to expect her to recover further. There appeared to be a lack of communication, with misunderstanding of terms such as "getting better" and "recovering".

Two days later, the patient died from a large cerebral hemorrhage caused by her fall.

\section{Case analysis}

Irrespective of issues such as understaffing, healthcare providers are responsible for patient safety during hospital stay. Interprofessional teamwork improves cooperation, coordination, and collaboration in delivering patient-centered care and increasing patient satisfaction. Interprofessional collaborative practice and team-based care are introduced as the forefront of a modern healthcare system.

According to the Interprofessional Education Collaborative (IPEC) report of 2011, ${ }^{[4]}$ there are four competencies to interprofessional collaborative practice. Two of those competencies are communication and teamwork. Investigating this case further, it was established that the two RNs were the main caregivers of the patient. Nurses and physicians work closely in the laminar flow room environment. It is widely accepted that environmental prevention measures can minimize infections in transplant populations. ${ }^{[4]}$ The routine treatment protocols were handled properly. Further issues in this case are discussed as follows.

First, the team was not aware of their ineffective communication with the patient and her family, which caused the misunderstanding of the patient's health condition and her non-compliance with the RNs' education. To the physician, "getting better" for a patient with severe aplastic anemia meant that the situation was under control. However, the family may have interpreted this differently. The physicians understood that there was no chance that the patient could be completely cured. However, the family did not realize this. Based on Nancarrow's ${ }^{[5]}$ article on the 10 principles of an interprofessional team, the team in this case did not utilize communication strategies that promote intra-team communication, collaborative decision-making and effective team processes. Physicians should value nurses' opinions, suggestions, and reports, because nurses spend the most time with and provide direct care for the patient. ${ }^{[6]}$ However, the doctor is responsible for clarifying the patient's and family members' misunderstandings regarding their disease, treatment options and prognosis.

Second, a key person in this case was the unit director, who is the team leader. The team leader is responsible for establishing a clear direction and vision for the team, while listening and providing support and supervision to team members. ${ }^{[5]}$ However, the team leader in this case was not apparent at any stage in the process, suggesting his role was not carried out correctly.

Third, sufficient staffing is required that accommodates nurses with a proper combinations of skills, competencies and personalities to meet patients' needs and enhance their function and progress. ${ }^{\left[{ }^{7,8]}\right.}$ In this case, there were only two RNs and one doctor involved in the patient's care. Other healthcare providers such as social workers and pharmacists may have played a role in the care of the patient. Sufficient staffing has a positive impact on patient outcomes. ${ }^{[9,10]}$ For example, social workers provide the necessary psychosocialspiritual support for oncology patients and families, ${ }^{[11]}$ and pharmacists actively participate in the multidisciplinary team to have a positive impact on patients' medical management and medication counseling. ${ }^{[12]}$

\section{IDENTIFIED STRATEGIES}

The persistence of hierarchy in multidisciplinary teamwork has been widely assumed for years. One of the obstacles to successful teamwork is dominance of the medical profession in team leadership, which has been described as possibly detracting from the achievement of positive patient outcomes. ${ }^{[13]}$ Based on a framework for action on interprofessional education and collaborative practice, ${ }^{[14]}$ strategies to improve the identified areas in this case analysis begin with team-building, which contributes to the effectiveness of teamwork and team-based care.

\section{Strategy A: Team-building}

An interprofessional team approach is a successful method for identifying areas. ${ }^{[15]}$ Physicians, bedside nurses, pharmacists and dieticians are included in an interprofessional team and play a vital role in collaborative patient care. A regular team meeting involving practitioners from a variety of disciplines is one interprofessional approach. Teamwork enables a focus on medical concerns, such as managing complicated symptoms, guiding nutritional intake, or checking a patient's mental status. A team case study meeting, held on a regular basis, provides health care practitioners with opportunities for interprofessional interaction and enables decision-making, as well as identification of the relevant 
problems in a case. ${ }^{[16]}$ Health care practitioners need more opportunities to explore such practices, and to better articulate what works in different clinical settings. ${ }^{[17]}$

These types of meetings have functional and social significance in team building. For example, in the case we reported on, a regular team meeting held to discuss the patient's mental state and health condition may have enabled earlier action before the situation exacerbated. Identification of the need to perform fall risk assessments in every shift and the provision of psychological consultation might have been made. More consideration and prevention would have been taken to take care of the patient through providing emotional support to the patient and caregivers. ${ }^{[18]}$

\section{Strategy B: Interprofessional education}

Interprofessional education is essential for professional development, which requires new knowledge, attitudes and skills when facilitating interdisciplinary education. ${ }^{[19,20]}$ Prelicensure education and unit cultures are key elements for interprofessional education. ${ }^{[21,22]}$ Research has concluded that developing effective teamwork skills is an appropriate emphasis for health professional students. ${ }^{[23]}$ Relationships among different professional students involving their values and beliefs can be built positively through learning. Collaboration and teamwork skills should be part of the curriculum for these students. Students will play different roles in the healthcare system after their graduation, and interprofessional education is beneficial in enhancing collaborative practice and improving patient outcomes.

\section{Strategy C: Communication}

Communication skills are a core competency in interprofessional teamwork. During patient consultations, physicians and nurses collect and assess an extensive amount of information in relatively short periods of time, while simultaneously reassuring and comforting patients and family members. Good communication skills are essential, and ineffective communication may leave patients feeling dissat- isfied or anxious. Ineffective communication may also lead to a lack of compliance with the suggested treatments. ${ }^{[24]}$ Unfortunately, not all physicians and nurses master good communication skills. They may be willing to receive training on communication skills, to provide a more effective communication style with their patients and their families. ${ }^{[25]}$

Evidence indicates that communication skills training courses are effective in improving healthcare professionals' supportive and communication skills, particularly for gathering information. ${ }^{[26]}$ Slort and colleagues ${ }^{[27]}$ reported significant outcomes on patient satisfaction in a controlled trial of a communication training program. Results of a randomized controlled trial of a scenario-based simulation course training on nurses' communication competence also emphasized the importance of introducing such training to nurse education. ${ }^{[28]}$

\section{RECOMMENDATIONS}

Nurse managers and unit directors can learn from our reported case, with regard to team building, collaboration and communication skills. As the nurse educators, they pay more attention to education about multidisciplinary cooperation. Meanwhile, curriculum developers across the health sciences are encouraged to evaluate their current educational content and adopt and test these competencies for interprofessional practice ${ }^{[29]}$ Interprofessional collaboration should be added to curriculum development in higher levels of healthcare education. Interprofessional education, practice and team building will facilitate healthcare providers to reach a collaborative level of clinical practice and provide more considerate healthcare to patients. Introducing a multidisciplinary team approach to healthcare professionals will enhance their performance in clinical practice and meet demands for high quality health care.

\section{Conflicts of InTEREST Disclosure}

The authors declare that there is no conflict of interest.

\section{REFERENCES}

[1] Del Sindaco D, Pulignano G, Minardi G, et al. Two-year outcome of a prospective, controlled study of a disease management programme for elderly patients with heart failure. J Cardiovasc Med. 2007 May; 8(5): 324-9.

[2] Houle SKD, Chatterley T, Tsuyuki RT. Multidisciplinary approaches to the management of high blood pressure. Curr Opin Cardiol. 2014 Jul; 29(4): 344-53. PMid:25029452 https : //doi .org/10.1097/ HCO. 0000000000000071

[3] Hazelton JP, Orfe EC, Colacino AM, et al. The impact of a multidisci- plinary safety checklist on adverse procedural events during bedside bronchoscopy-guided percutaneous tracheostomy. J Trauma Acute Care Surg. 2015 Jul; 79(1): 111-6.

[4] Hicheri Y, Einsele Y, Martino R, et al. Environmental prevention of infection in stem cell transplant recipients: a survey of the Infectious Diseases Working Party of the European Group for Blood and Marrow Transplantation. Transpl Infect Dis. 2013; 15: 251-8. PMid:23465046 https : //doi.org/10.1111/tid. 12064

[5] Nancarrow S, Booth A, Ariss S, et al. Ten principles of good interdisciplinary team work. Hum Resour Health. 2013; 11(1): 19. 
PMid:23663329 https : //doi.org/10.1186/1478-4491-11-1 9

[6] Hurst K. How much time do nurses spend at the bedside? Nurs Stand. 2010 Sep; 24(52): 14-14.

[7] Bostick JE, Rantz MJ, Flesner MK, et al. Systematic Review of Studies of Staffing and Quality in Nursing Homes. J Am Med Dir Assoc. 2006 Jul; 7(6): 366-76.

[8] Butler M. Hospital nurse staffing models and patient and staff-related outcomes. Collins R, Drennan J, Halligan P, O’Mathúna DP, Schultz TJ, Sheridan A, et al., editors. Cochrane Database Syst Rev [Internet]. 2011 Jun 13 [cited 2015 Apr 27]; (7). Available from: http://ezproxy . chatham.edu:2048/login?url=http:

//search.ebscohost. com/login. aspx?direct=true\&db=ch h\&AN=CD007019\&site $=$ ehost - live

[9] Stalpers D, de Brouwer BJM, Kaljouw MJ, et al. Associations between characteristics of the nurse work environment and five nursesensitive patient outcomes in hospitals: A systematic review of literature. Int J Nurs Stud. 2015 Apr; 52(4): 817-35.

[10] Sung-Heui Bae, Kelly M, Brewer CS, et al. Analysis of Nurse Staffing and Patient Outcomes Using Comprehensive Nurse Staffing Characteristics in Acute Care Nursing Units. J Nurs Care Qual. 2014 Oct; 29(4): 318-26.

[11] Otis-Green S, Jones B, Zebrack B, et al. ExCEL in Social Work: Excellence in Cancer Education \& Leadership: An Oncology Social Work Response to the 2008 Institute of Medicine Report. J Cancer Educ. 2014 Aug 23; 1-11.

[12] Wilson L, Orff S, Gerry T, et al. Evolution of an innovative role: the clinical nurse leader. J Nurs Manag. 2013 Jan; 21(1): 175-81.

[13] Gair G, Hartery T. Medical dominance in multidisciplinary teamwork: A case study of discharge decision-making in a geriatric assessment unit. J Nurs Manag. 2001; 9: 3-11. https://doi.org/10.1046/ j.1365-2834.2001.00200.x

[14] Gilbert JHV, Yan J, Hoffman SJ. A WHO Report: Framework for Action on Interprofessional Education and Collaborative Practice. J Allied Health. 2010 Sep 1; 39(3): 196-7. PMid:21174039

[15] Valgus JM, Aimee F, Gregory KM, et al. Integration of a clinical pharmacist into the hematology-oncology clinics at an academic medical center. Am J Health Syst Pharm. 2011; 68: 613-9. PMid:21411803 https://doi.org/10.2146/ajhp100414

[16] Bridges DR, Davidson RA, Odegard PS, et al. Interprofessional collaboration: three best practice models of interprofessional education. Med Educ Online. 2011 Jan; 16(1): 1-10.

[17] Di Giulio P, Arnfield A, English MW, et al. Collaboration between doctors and nurses in children's cancer care: insights from a European project. Eur J Oncol Nurs. 2013; 17: 745-9. PMid:23462303 https://doi.org/10.1016/j.ejon.2013.01.003

[18] Lazure P, St-germain F, Gryfe R, et al. Communication-the foundation for collaborative relationships amongst providers, and between providers and patients: A case in breast and colorectal cancer. J Com- mun Healthc. 2014; 7(1): 41-56. https ://doi .org/10.1179/17 53807614 Y. 0000000047

[19] Hall P, Weaver L. Interdisciplinary education and teamwork: a long and winding road. Med Educ. 2001; 35(9): 867-75. https: //doi.org/10.1046/j.1365-2923.2001.00919.x

[20] MacNaughton K, Chreim S, Bourgeault IL. Role construction and boundaries in interprofessional primary health care teams: a qualitative study. BMC Health Serv Res. 2013; 13: 486. PMid:24267663 https://doi.org/10.1186/1472-6963-13-486

[21] Tang CJ, Chan SW, Zhou WT, et al. Collaboration between hospital physicians and nurses: An integrated literature review. Int Nurs Rev. 2013; 60(65): 291-302. PMid:23961790 https ://doi.org/10.1 $111 /$ inr. 12034

[22] Kraemer E, Kahanov L. Development of Interprofessional Education for Entry-Level Athletic Training Programs. Int J Athl Ther Train 2014 Nov; 19(6): 4-7. https://doi.org/10.1123/ijatt. 2014 $-0046$

[23] Horsburgh M, Lamdin R, Williamson E. Multiprofessional learning: The attitudes of medical, nursing and pharmacy students to shared learning. Med Educ. 2001; 35: 876-83. https ://doi.org/10.1 046/j.1365-2923.2001.00959.x

[24] Hagerty RG, Butow PN, Ellis PM, et al. Communicating prognosis in cancer care: a systematic review of the literature. Ann Oncol. 2005 Jul 1; 16(7): 1005-53

[25] Berkhof M, van Rijssen HJ, Schellart AJM, et al. Effective training strategies for teaching communication skills to physicians: An overview of systematic reviews. Patient Educ Couns. 2011; 84(2): 152-62. PMid:20673620 https://doi.org/10.1016/j.pec. 20 10.06 .010

[26] Moore PM. Communication skills training for healthcare professionals working with people who have cancer. Rivera Mercado S, Grez Artigues M, Lawrie TA, editors. Cochrane Database Syst Rev [Internet]. 2015 Apr 1 [cited 2015 Apr 27]; (4). Available from: http: //ezproxy . chatham .edu: 2048/login?url=http: //search.ebscohost. com/login. aspx?direct $=$ true\&db $=c h$ h\&AN $=$ CD003751\&site $=$ eds - live\&s cope=site

[27] Slort W, Blankenstein AH, Schweitzer BP, et al. Effectiveness of the palliative care "Availability, Current issues and Anticipation" (ACA) communication training programme for general practitioners on patient outcomes: A controlled trial. Palliat Med. 2014 Sep; 28(8): 1036-45.

[28] Hsu LL, Chang WH, Hsieh SI. The Effects of Scenario-Based Simulation Course Training on Nurses' Communication Competence and Self-Efficacy: A Randomized Controlled Trial. J Prof Nurs. 2015 Feb; 31(1): 37-49. PMid:25601244 https ://doi.org/10.1016/ j.profnurs. 2014.05.007

[29] Fishman SM, Young HM, Lucas AE, et al. Core competencies for pain management: Results of an interprofessional consensus summit. Pain Med U S. 2013; 14: 971-81. PMid:23577878 https : //doi.org/10.1111/pme.12107 